\title{
Practice of Behaviour Modification Techniques by Pre-Service Teacher Interns of Colleges of Education in Ghana
}

\author{
Grace Yeboah $^{1 *}$, Kyeremeh Tawiah Dabone ${ }^{2}$, Grace Aba Mensah ${ }^{3}$ \\ ${ }^{1}$ St. Louis College of Education, Kumasi, Ghana \\ ${ }^{2}$ Counselling Centre, University of Cape Coast, Cape Coast, Ghana \\ ${ }^{3}$ Wesley College of Education, Kumasi, Ghana \\ Email: *adikuodoe@yahoo.co.uk
}

How to cite this paper: Yeboah, G., Dabone, K. T., \& Mensah, G. A. (2020). Practice of Behaviour Modification Techniques by Pre-Service Teacher Interns of Colleges of Education in Ghana. Open Journal of Social Sciences, 8, 245-258.

https://doi.org/10.4236/jss.2020.810016

Received: July 27, 2020

Accepted: October 26, 2020

Published: October 29, 2020

Copyright $\odot 2020$ by author(s) and Scientific Research Publishing Inc. This work is licensed under the Creative Commons Attribution International License (CC BY 4.0)

http://creativecommons.org/licenses/by/4.0/

\section{(c) (i) Open Access}

\begin{abstract}
Since the primary aim of every teacher is to create and maintain positive learning environment for learners, it is logical to admit that the teacher must have in-depth knowledge and skills which address disciplinary issues and educational needs especially in the classroom. It was on account of this that this study was undertaken to assess the level of practice of behaviour modification technique in the classroom by pre-service teacher interns using a cross-sectional survey design. Data collected from 360 respondents at Colleges of Education in Ghana and analyzed using a three-point Likert-type scale questionnaire, reveal that the pre-service teacher interns do not regularly practice most of the behaviour modification techniques expected to be used for effective classroom management during the internship programme. The findings further showed no significant differences between male and female respondents in their practice of behaviour modification techniques. In like manner, it was largely evident, that the programme of study for the pre-service teacher interns had no significant effect on their practice of behaviour modification techniques. It is in the light of the above findings that this study makes a helpful recommendation to strengthen teacher training institutions in addressing such deficiencies in the formation programme in Ghana.
\end{abstract}

\section{Keywords}

Pre-Service Teachers, Colleges of Education, Gender, Programme of Study, Behaviour Modification Techniques

\section{Introduction}

One fundamental issue in the field of education is the preparation and training 
of teachers who are described "as the most significant resource in schools" and "are central to school improvement efforts" (OECD, 2005). For Vegas, Ganimian, and Jaimovich (2012), an education system is only as good as its teachers. At the same time, evidence from different education systems around the world also shows that the most important factor in determining how well children perform is the quality of teachers and teaching (The Schools White Paper, 2010). Way (2001), stressed that teachers are regarded as the agents of change for students and for schools. According to Way, one key factor to improve schools is fostering teacher development which helps their craft, shapes school practices, and builds learning communities. Since teachers' preparation programmes bear great impacts on the teacher's ability to provide effective and efficient instructional services and management of a class, pre-service teachers' training programmes must focus on providing the requisite theoretical knowledge and practical experiences that would enable them create the conducive environment necessary for teaching and learning and also help them become successful teachers. This is particularly necessary because, all through their career, classroom discipline ranks foremost among the many and frequent issues teachers may have to confront.

Discipline, therefore, comes to the forefront with two broad objectives in the school environment are firstly, to ensure the safety of staff and students and, secondly, to create an atmosphere conducive to learning (Gaustard, 2005). To many students, discipline connotes punishment, pain and fear. Yet, it possesses far greater merit than this perception; it has more to do with the correction of undesirable behaviour at home, in the school or at any place (Narebe, 2013). In Mclntosh (2013) The Cambridge Advanced Learners Dictionary discipline is defined as training that makes people more willing to obey or help them to control themselves, often in the form of rules and regulations which, when broken or not adhered to, results in negative consequences in the form of punishment. Alhassan (2000) explains the concept of discipline as training that ensures that an individual develops orderly conduct, self-control as well as self-direction. For Were (2006), discipline, is a system of guiding the individual to make rational decisions sensibly. It is also an action taken by grown-ups to help a child amend his or her behaviour. Discipline, therefore, forms part of moral education which is significant in the development of the child's character (Were, 2006). Perkins (1969), on his part, defines discipline as the task of helping students to utilize their abilities, energies, and talents in ways that promote their development and learning. All of this may concord with the earlier educational doctrine of Beery (1917) who held that discipline was not punishment but the training of every power to the end that it may be controlled and used for personal good and social service. In the light of this appreciation, the disciplinarian was seen as one who helped each individual for whom they were responsible to bring those powers under control and to use them in such a way that they should become a useful member of society (Beery 1917). Generally, traditional views of discipline applied to the classroom emphasize that teacher control of pupil behaviour is essential for learning (Neill, 1978, cited by Kohut \& Dale, 1979). 
Nonetheless, global evidence shows that there is indiscipline in schools (ProTeacher, 2005; Reid, 2000), and to Ngwokabuenui (2015), students' indiscipline is instigating a menace in all parts of the world in relation to children's affairs. In the study of Curwin and Mendler (1988), 15\% of students break classroom rules regularly and if sufficient structure is not put in place to arrest the situation, these misguided individuals could disrupt the learning process of other students. In addition to this, a study of 479-teacher samples from preschools to eighth-grade established that $48 \%$ of the teachers reported to have had three or more students in their classrooms exhibiting serious behavioural difficulties (ProTeacher, 2005); Shin and Koh (2008) also point out that 32\% out of 116 public high school teachers have indicated that $25 \%-50 \%$ of their students have behavioural challenges and are difficult to teach. Since indiscipline impinges on learning activities in the school environment, better management and solutions should be rolled out to arrest it.

Accordingly, and in recent years, behaviour modification has gained the attention of researchers in the field of education owing to its significant effects in improving children's behaviour through increasing desired behaviour and decreasing undesired behaviour (Eshun, 2016). According to Alkhateeb \& Alhadidi, who are cited in Al-Bustanji, Almakanin, Beirat and Bdour (2018), behaviour modification has important implications in teaching strategies and techniques when used with children, especially those with special needs regardless of their disabilities. Indeed, as a well-managed classroom can provide an exciting and dynamic learning experience for everyone, its opposite could also overwhelm teachers, rendering them "powerless" in dealing with behavioural issues in the classroom environment. Canter, as cited in Kakkad (2012) explains that, in the past, a simple stern look or warning was appropriate to shape up a classroom. Therefore, it is important to find a behaviour modification approach which suits the needs of both the teacher and student. This directs the attention to the content of teacher training programmes and their effectiveness in the classroom.

Although there has been a lot of study done with regard to pre-service teachers' exposure to effective instructional management in their training, there still exists a significant gap between students' effective instructional management knowledge and the requirements necessary for teacher training. As a result, many pre-service teachers, even upon completion of teacher education programme, are inadequately prepared to effectively manage student behaviour due to their lack of exposure to classroom management content (Shamina \& Mumthas 2018). Indeed, not much research has gone into this area of teacher formation but a few available studies have examined the extent to which behaviour modification management content has been included in pre-service teacher preparation programmes (Stough, 2006). As part of their study of 19 tertiary institutions in the north-eastern USA, Wesley and Vocke (1992), underscored the fact that majority of the programmes included instruction in classroom discipline. In the work of Blum (1994), over half of programmes had units on classroom management even though the units were not mandatory for $43 \%$ of enrolled students. 
Certainly, there is the general belief that training pre-service teachers receive insufficient classroom behaviour management content, equipped with the needed knowledge and skills to make them successful teachers. There is, therefore, a huge gap between the pre-service teachers' training and their practice on the field (Al-Bustanji, Almakanin, Beirat, \& Bdour, 2018).

Studies done on the effect of the teacher's qualities, like gender and programme of study on their belief of classroom discipline suggest that there is no significant difference between males and females in their practice of behaviour modification even though males are generally considered do better than females (Bukhari, 2016). Other studies that considered the effect of programme of study on the practice of behaviour modification techniques by pre-service teachers indicated no general disparity in how students of colleges of education applied their knowledge of behaviour modification (Brace, 2017; Muller, 2015).

In Ghana, little research has gone into the practice of behaviour modification techniques by pre-service teachers. Available literature focuses on behaviour modification techniques used by teachers in service. Notable authors include Aponsem (2015), Eshun (2016), Ahiapko (2016) and Narebe (2013). Aponsem, for instance, studied the relationship between behaviour modification practices of teachers and pupils' attendance in the Eastern Region of Ghana and Eshun investigated behaviour modification strategies adopted by teachers in some selected schools in Ashanti Region. Also, Ahiapko carried out a study which looked into behaviour modification techniques adopted by Senior High School teachers in five districts in the Volta Region and Narebe, on his part, assessed the knowledge of teachers on behaviour modification strategies in Tamale, Ghana. However, this current work examined the practice of behaviour modification strategies by pre-service teachers in the classroom, seeking to determine the effect of gender and programme of study on the practice of behaviour modification strategies used by final year pre-service teachers on internship. It was on the basis of this that research questions were formulated.

\section{Research Questions}

This study was guided by the following research questions:

1) How do pre-service teacher interns of Colleges of Education rate their practice of behaviour modification techniques in the classroom?

2) How does gender affect the ratings of pre-service teacher interns' practice of behaviour modification techniques in the classroom?

3) How does programme of study affect the ratings of pre-service teacher interns' practice of behaviour modification techniques in the classroom?

\section{Research Methodology}

\subsection{Research Design}

A cross-sectional survey design was used for this study. According to Neuman (2000), cross-sectional surveys are appropriate for situations where the data to 
be collected are about self-reported beliefs or behaviour. This design helps to collect data to make inferences about a population of interest at one point in time. Besides, it enables the researcher to collect data and compare many different variables at the same time without manipulations.

\subsection{Population and Sample Size}

Colleges of Education in the Ashanti Region of Ghana were considered for the study. This is because Ashanti Region has nine (9) Colleges of Education, which is one of the highest in Ghana. The total number of final year pre-service teachers in these Colleges was 3225. This 3225 comprise Agogo Presbyterian College of Education = 392; Agona SDA College of Education = 142; Akokerri College of Education $=433$; Christ the Teacher College of Education $=30$; Mampong Technical College of Education $=440$; St Monica's College of Education $=456$; St. Louis College of Education $=427$; Wesley College of Education $=412$ and Offinso College of Education $=492$. A stratified random sampling technique was used to obtain the number of respondents from the various colleges of education. A total sample size of 370 was determined using the mathematical formula:

$$
n=N /\left[1+N(\alpha)^{2}\right]
$$

where $n=$ sample size; $N=$ sampling frame; $\alpha=$ confidence level (Adei \& Kunfaa, 2007). A simple random sampling technique was used to obtain the actual respondents of each College of Education through a computerized table of random method. The sample size obtained for the 9 colleges of education were Agogo Presbyterian College of Education = 45; Agona SDA College of Education = 17; Akokerrri College of Education $=50$; Christ The Teacher College of Education $=3$; Mampong Technical College of Education $=50$; St Monica's College of Education = 52; St. Louis College of Education = 49; Wesley College of Education $=47$ and Offinso College of Education $=57$.

\subsection{Research Instrument}

A Behaviour Modification Questionnaire (BMQ) developed by the researchers was used for the study. The questionnaire consisted of two (2) parts. The first part consisted of 5 items that dealt with the demographic data of the respondents namely: gender, programme of study and the name of the college of education. The second part was to elicit information to measure the pre-service teachers' level of practice on behaviour modification techniques in the classroom. It consisted of 16 items constructed on a three-point Likert scale with the responses: Most of the time, some of the time and never. A pilot study was conducted to assess the validity (internal consistency) and reliability of the questionnaire to enhance its accuracy for the data collection. Participants for the pilot study were selected from Bechem College of Education in the Ahafo Region of Ghana. The Cronbach's alpha which is a measure of the reliability (internal consistency) of the instrument was calculated as 0.70 which is considered high in most social science research applications. 


\subsection{Data Collection Procedure}

The data for the study was collected using three-point Likert scale questionnaire at a single point in time as indicated earlier. The questionnaires were administered by the researchers directly to the participants in March, 2019. A total number of 370 questionnaires were distributed. The number of questionnaires which were successfully completed and returned were 360 . This represents a return rate of $90 \%$. On the spot method of administration and retrieval was used to improve the return rate. All ethical procedures required were followed. Participants were made to indicate their willingness to participate in the study and directives on the questionnaires ensured respondents' anonymity and confidentiality.

\subsection{Data Analysis}

The data were analysed using descriptive and inferential statistics. Statistical software used for the analyses was the Statistical Package for Social Scientists (SPSS). The means and standard deviations of the ratings for each of the items were computed and the means compared to the theoretical mean rating (assuming a normal distribution of responses) to ascertain the respondents' perception on the indicators considered. Additionally, the effect of gender and programme of study on respondents' practice of classroom behaviour modification techniques were determined. An item-by-item t-test and analysis of variance (ANOVA) at 5\% level of significance was performed to establish a possible significant difference in the respondents' ratings of the indicators of this study. $p$-values, lower than 0.05 were deemed significant.

\section{Results and Discussions}

\subsection{Ratings of Pre-Service Teacher Interns on Practices of Behaviour Modification Techniques}

Effective teaching and learning cannot take place in poorly managed classrooms (Jones \& Jones, 2012; Van de Grift, Van der Wal, \& Torenbeek, 2011). Therefore, it is required that teachers select and use the most appropriate classroom management strategies that will support and facilitate effective teaching and learning. This result indicates the ratings of pre-service teacher interns on their practice of behaviour modification techniques in the classroom after their internship programme. The means and standard deviations indicated in Table 1 were computed from the ratings of the respondents on the various indicators of the respondents' practice of behaviour modification techniques in the classroom using a three-point Likert-scale questionnaire. The respondents were to rate their responses on the items "most of the time $=3$ ", "some of the time $=2$ " and "never $=1$ ". The theoretical mean was 2 . Thus, ratings above 2 were deemed high extent of practice of behaviour modification techniques in the classroom during the internship programme. On the contrary, ratings below 2 were deemed low extent of practice of behavior modification techniques in the classroom during the internship programme. The mean ratings of the 360 respon- 
dents on their practice of behaviour modification techniques in the classroom ranged from $1.31(S D=1.51)$ to $2.43(S D=0.75)$. Further to this, for 7 out of the 16 items, the mean ratings of the respondents were greater than 2 which suggest that the pre-service teachers during their internship programme very often practised that behaviour modification technique. However, with 9 of the items, the mean ratings of the respondents were less than 2 suggesting that they did not regularly practise those techniques during their internship programme. The results (in Table 1) also indicated that the overall mean ratings of the respondents was 1.85 , suggesting that generally, the pre-service teacher interns seldom practised those behaviour modification techniques used in the classroom. Items that were rated below 2 were: "I motivate my students when I want to strengthen a behaviour", "I use a lot of reinforcement strategies so that students will enjoy my lessons", "I commend students for putting up good behaviour", "I do not cane students; I employ other forms of behaviour modification", I demonstrate the positive behaviour that I want students to practice", "I reward good behaviour with tangible items", "I reward good behaviour with praise", "I give special privileges to student for good behaviour", and "I verbally reprimand students for inappropriate behaviour".

Table 1. Practice of behaviour modification techniques by pre-service teacher interns.

\begin{tabular}{|c|c|c|c|}
\hline SN & Item & Mean & $\mathrm{SD}$ \\
\hline 1 & I don't punish students for their negative behaviour & 2.02 & 0.72 \\
\hline 2 & I motivate my students when I want to strengthen a behaviour & 1.31 & 1.52 \\
\hline 3 & $\begin{array}{l}\text { I overlook all forms of disruptive behaviour because I don't want to be } \\
\text { reported to my mentor }\end{array}$ & 2.31 & 0.81 \\
\hline 4 & $\begin{array}{l}\text { I don't punish students for disruptive behaviour to encourage them to be } \\
\text { punctual to school }\end{array}$ & 2.21 & 0.75 \\
\hline 5 & I use a lot of reinforcement strategies so that students will enjoy my lessons & 1.54 & 0.70 \\
\hline 6 & $\begin{array}{l}\text { I cane students for disruptive behaviour. It is the best form of behaviour } \\
\text { modification. }\end{array}$ & 2.17 & 0.75 \\
\hline 7 & I commend students for putting up good behaviour & 1.44 & 1.25 \\
\hline 8 & I do not cane students; I employ other forms of behaviour modification & 1.62 & 0.64 \\
\hline 9 & I demonstrate the positive behaviour that I want students to practice & 1.36 & 0.57 \\
\hline 10 & I reward good behaviour with tangible items & 1.66 & 0.65 \\
\hline 11 & I reward good behaviour with praise & 1.39 & 0.58 \\
\hline 12 & I give special privileges to student for good behaviour & 1.72 & 0.69 \\
\hline 13 & I send disruptive students out of the classroom & 2.43 & 0.76 \\
\hline 14 & I take away some privilege for disruptive behaviour & 2.19 & 0.73 \\
\hline 15 & I use time-out for disruptive students & 2.21 & 0.73 \\
\hline \multirow[t]{2}{*}{16} & I verbally reprimand students for inappropriate behaviour & 1.99 & 0.73 \\
\hline & Mean of means & 1.85 & 0.79 \\
\hline
\end{tabular}

Source: Field Survey, Yeboah (2019) N = 360 . 
In this study, the pre-service teacher interns indicated that they did cane learners who put up disruptive behaviour (Mean rating 2.17) even though corporal punishment is prohibited by the instructional norms of the Ghana Education Service. Boakye (2001) and Edumadze (2004) hold that Ghanaian teachers still use corporal and other forms of subversive punishment because these facilitate teaching and learning. Additionally, the pre-service teacher interns reported of their use of time-out to manage disruptive behaviour in the classroom; they judged it as a non-violent measure of disciplining unruly behaviour with minimal damaging effects on children. This is in line with Main and Hammond's study (2008) also underscored the fact that pre-service teachers predominantly reported observing time-out, both in class and out of class as the most frequently observed approach. On another level, this study also revealed that respondents did not often reward good behaviour with tangible items due to lack of funds to sustain such a practice. Some of the pre-service teacher interns admitted to not punishing students for disruptive behaviour in order to encourage them to be punctual at school. This is similar to a study by Kalagho (2014), indicating that $78 \%$ of the respondents admitted to have ignored disruptive behaviour of students in view of the fact that some pupils put up disruptive behaviour to provoke and seek attention. If they do receive the attention they crave, there is the likelihood that the unruly behaviour will repeat itself, but if attention is denied them, the misbehaviour dissipates on its own (Kalagho, 2014).

\subsection{Effects of Gender on Practice of Behaviour Modification Techniques by Pre-Service Teacher Interns}

Table 2 presents the results of mean ratings of respondents by gender and t-test analysis to access the effects of gender on practice of behaviour modification by pre-service teacher interns during internship programme. The item-by-item mean ratings of the male pre-service teacher interns ranged between $1.33-2.31$ while that of the females ranged between $1.29-2.51$. Out of the 16 items, the male respondents largely employed 6 for class management while their female counterparts indicated their use of 8 during their internship programme. This suggests that the female teacher interns used more behaviour modification techniques for classroom management than their male colleagues. This could be grounded on the belief that female teachers are more custodial and stick to the classroom ground rules and more persistent in controlling disruptive behaviour as compared to males in the view of Hakan and Esergül (2015).

Item-by-item comparison of means (Table 2) to assess the effect of gender on the respondents' ratings of their practice of behaviour modification techniques during an internship programme indicated that at $5 \%$ level of significance thirteen (13) out of the sixteen (16) items showed no significant effects of gender on the respondents' practice of behaviour modification techniques.

On the contrary, with three (3) out of the sixteen (16) items at 5\% level of significance, there was significant difference in the ratings of the respondents by gender with that of the females being significantly higher than that of the males. 
Table 2. T-test of effect of gender on knowledge of knowledge of pre-service teachers on behaviour modification techniques.

\begin{tabular}{|c|c|c|c|c|c|c|c|}
\hline \multirow{2}{*}{$\begin{array}{l}\text { Item } \\
\text { No }\end{array}$} & \multirow{2}{*}{ Items } & \multicolumn{2}{|c|}{ Male $(\mathrm{n}=145)$} & \multicolumn{2}{|c|}{ Female $(\mathrm{n}=215)$} & \multirow{2}{*}{$\mathrm{T}$} & \multirow{2}{*}{$p$-value } \\
\hline & & Mean & $\mathrm{SD}$ & Mean & SD & & \\
\hline 1 & Don’t Punish Negative Behaviour & 1.97 & 0.756 & 2.06 & 0.684 & -1.236 & $0.217^{\dagger}$ \\
\hline 2 & Motivate & 1.33 & 0.541 & 1.29 & 0.512 & 0.758 & $0.449^{\dagger}$ \\
\hline 3 & Overlook Behaviour & 2.17 & 0.850 & 2.41 & 0.761 & -2.843 & $0.006^{*}$ \\
\hline 4 & Don't Punish Disruptive Behaviour & 2.17 & 0.785 & 2.23 & 0.718 & -0.751 & $0.456^{\dagger}$ \\
\hline 5 & Reinforce Strategies & 1.39 & 0.627 & 1.64 & 0.735 & -3.274 & $0.001^{*}$ \\
\hline 6 & Cane Students & 2.11 & 0.826 & 2.21 & 0.698 & -1.282 & $0.216^{\dagger}$ \\
\hline 7 & Commend Students & 1.54 & 1.818 & 1.36 & 0.603 & 1.362 & $0.174^{\dagger}$ \\
\hline 8 & Don't Cane Students & 1.62 & 0.657 & 1.62 & 0.622 & 0.310 & $0.976^{\dagger}$ \\
\hline 9 & Demonstrate positive Behaviour & 1.39 & 0.580 & 1.35 & 0.588 & 0.613 & $0.540^{\dagger}$ \\
\hline 10 & Reward with Items & 1.70 & 0.670 & 1.63 & 0.634 & 0.918 & $0.359^{\dagger}$ \\
\hline 11 & Reward with Praise & 1.41 & 0.596 & 1.39 & 0.579 & 0.332 & $0.740^{\dagger}$ \\
\hline 12 & Special Privileges & 1.69 & 0.672 & 1.74 & 0.708 & -0.669 & $0.504^{\dagger}$ \\
\hline 13 & Send Students out of the classroom & 2.31 & 0.804 & 2.51 & 0.716 & -2.431 & $0.016^{*}$ \\
\hline 14 & Take Away Privileges & 2.23 & 0.705 & 2.51 & 0.747 & 0.826 & $0.409^{\dagger}$ \\
\hline 15 & Time out & 2.13 & 0.766 & 2.27 & 0.705 & -1.768 & $0.078^{\dagger}$ \\
\hline 16 & Verbal Reprimand & 1.97 & 0.735 & 2.01 & 0.723 & -0.471 & $0.638^{\dagger}$ \\
\hline
\end{tabular}

${ }^{\star}$ Statistically significant at 0.05 level of significance; ${ }^{\dagger}$ Not statistically significant at 0.05 level of significance.

With item number 5 , reinforce strategies, the mean rating of both the male and female respondents suggests that they did not usually use this technique for managing their classrooms. In this study, the finding that teachers generally do not statistically and significantly differ in their practice of behaviour modification techniques by gender is consistent with that of Okafor (2015) and Bukhari (2016) who maintain that gender does not significantly affect the practice of behaviour modification techniques. This may be grounded on the fact that teachers, male or female, are trained by the same curriculum, and as a result, express not much difference in their practice of their acquired knowledge.

\subsection{Effect of Programme of Study on Practices of Pre-Service Teachers on Behaviour Modification Techniques}

Table 3 shows the result of a one-way ANOVA to determine the effect of programme of study on the participants' practice of behaviour modification techniques. It also indicates the mean ratings of the pre-service teacher interns studying Mathematics, Technical Education, Early Childhood, General Education and French on their practice of classroom behaviour modification techniques. The range of the mean ratings for the five programmes was as follows: Mathematics $=1.26(0.526)-2.15(0.718) ;$ Technical Education $=1.29(0.468)-2.29$ 
Table 3. ANOVA of the effect of programme of study on practice of behaviour modification techniques by pre-service teachers' interns.

\begin{tabular}{|c|c|c|c|c|c|c|c|c|c|c|c|c|c|}
\hline \multirow{3}{*}{$\begin{array}{l}\text { Item } \\
\text { number }\end{array}$} & \multirow{3}{*}{ Item } & \multirow{2}{*}{\multicolumn{2}{|c|}{$\begin{array}{l}\text { Mathematics } \\
\text { \& Science }\end{array}$}} & \multicolumn{2}{|c|}{ Technical } & \multirow{2}{*}{\multicolumn{2}{|c|}{$\begin{array}{c}\text { Early } \\
\text { Childhood }\end{array}$}} & \multirow{2}{*}{\multicolumn{2}{|c|}{$\begin{array}{c}\text { General } \\
\text { Educations }\end{array}$}} & \multirow{2}{*}{\multicolumn{2}{|c|}{$\begin{array}{l}\text { French } \\
(\mathrm{n}=12)\end{array}$}} & \multirow{3}{*}{$\mathrm{F}$} & \multirow{3}{*}{$p$-value } \\
\hline & & & & \multicolumn{2}{|c|}{$(\mathrm{n}=14)$} & & & & & & & & \\
\hline & & Mean & SD & Mean & SD & Mean & SD & Mean & SD & Mean & SD & & \\
\hline 1 & $\begin{array}{c}\text { Don't Punish Negative } \\
\text { Behaviour }\end{array}$ & 1.89 & 0.698 & 1.86 & 0.525 & 2.18 & 0.809 & 2.03 & 0.720 & 2.17 & 0.718 & 0.742 & $0.564^{\dagger}$ \\
\hline 2 & Motivate & 1.52 & 0.700 & 1.36 & 0.633 & 1.41 & 0.712 & 1.28 & 0.478 & 1.33 & 0.551 & 1.578 & $0.180^{\dagger}$ \\
\hline 3 & Overlook Behaviour & 1.89 & 0.801 & 2.29 & 0.825 & 2.65 & 0.606 & 2.33 & 0.807 & 2.33 & 0.778 & 2.691 & $0.631^{\dagger}$ \\
\hline 4 & $\begin{array}{c}\text { Don't Punish } \\
\text { Disruptive Behaviour }\end{array}$ & 2.07 & 0.675 & 2.00 & 0.784 & 2.12 & 0.485 & 2.23 & 0.760 & 2.42 & 0.793 & 0.831 & $0.502^{\dagger}$ \\
\hline 5 & Reinforce Strategies & 1.30 & 0.609 & 1.29 & 0.469 & 1.53 & 0.717 & 1.58 & 0.717 & 1.42 & 0.669 & 1.599 & $0.174^{\dagger}$ \\
\hline 7 & Commend Students & 2.00 & 4.029 & 1.50 & 0.650 & 1.29 & 0.470 & 1.38 & 0.613 & 1.58 & 0.793 & 1.636 & $0.165^{\dagger}$ \\
\hline 8 & Don't Cane Students & 1.67 & 0.620 & 1.71 & 0.611 & 1.24 & 0.437 & 1.62 & 0.634 & 1.42 & 0.793 & 2.362 & $0.053^{\dagger}$ \\
\hline 9 & $\begin{array}{c}\text { Demonstrate Positive } \\
\text { Behaviour }\end{array}$ & 1.59 & 0.694 & 1.36 & 0.633 & 1.41 & 0.618 & 1.33 & 0.541 & 1.50 & 0.674 & 1.506 & $0.200^{\dagger}$ \\
\hline 10 & Reward with Items & 1.56 & 0.698 & 1.86 & 0.493 & 1.35 & 0.493 & 1.67 & 0.640 & 1.83 & 0.835 & 1.692 & $0.151^{\dagger}$ \\
\hline 11 & Reward with Praise & 1.26 & 0.526 & 1.64 & 0.633 & 1.24 & 0.437 & 1.40 & 0.586 & 1.58 & 0.669 & 1.643 & $0.163^{\dagger}$ \\
\hline 12 & Special Privileges & 1.59 & 0.694 & 1.71 & 0.726 & 1.88 & 0.781 & 1.71 & 0.684 & 1.92 & 0.793 & 0.706 & $0.588^{\dagger}$ \\
\hline 13 & $\begin{array}{c}\text { Send Student } \\
\text { out of the Classroom }\end{array}$ & 1.96 & 0.759 & 2.29 & 0.825 & 2.71 & 0.588 & 2.47 & 0.758 & 2.33 & 0.492 & 3.561 & $0.007^{*}$ \\
\hline 15 & Time out & 1.92 & 0.730 & 2.29 & 0.820 & 1.65 & 0.606 & 2.27 & 0.722 & 2.33 & 0.651 & 4.209 & $0.002^{*}$ \\
\hline 16 & Verbal Reprimand & 2.15 & 0.718 & 1.86 & 0.770 & 2.24 & 0.664 & 1.98 & 0.732 & 1.92 & 0.669 & 0.975 & $0.422^{\dagger}$ \\
\hline
\end{tabular}

*Statistically significant at 0.05 level of significance; ${ }^{\dagger}$ Not statistically significant at 0.05 level of significance.

(0.825); Early Childhood = $1.24(0.427)-2.71(0.588)$; General Education $=1.28$ $(0.478)-2.73(0.724)$ and French $=1.33(0.551)-2.42(0.793)$. The result generally indicates that the item-by-item mean ratings of the respondents according to the programme of studies were lower than or closer to the theoretical mean of 2.0. Therefore, the level of practice of the pre-service teacher interns of these five (5) programmes on classroom behaviour modification techniques was low.

The result (in Table 3) also indicates that at 5\% level of significance there was no significant difference between the mean ratings of the respondents according to their programme of study ( $p$-value $>0.05$ ). Exception to this were three (3) items: numbers 13 (Send student out of the classroom), 14 (Take away privileges) and 15 (Time out) which indicated a significant difference in the ratings of the participants for the various programmes. The results, therefore, suggest that the participants, who were of different academic programmes, had similar practice of behaviour modification in classroom management and thus, coincides with aspects of Skinner's as cited in Mukadam, Vyas and Nayak (2014) by pro- 
grammed instruction which suggest that learners of similar ages and characteristics must be measured with same treatment with regard to instructional management. In the light of this knowledge, trainers of teachers have largely and consistently ensured that students are uniformly taught with the same content across the board. It stands, therefore, to reason that the practice of behaviour modification in classroom management is similar among participants from the different programmes of learning. This is because pre-service teachers of different programmes of study are taken through the same content with respect to management of lessons.

The finding of this study is consistent with Brace's (2017) which indicated in a cross-cultural study that there were no significant differences in how students of Colleges of Education apply their knowledge of behaviour modification techniques irrespective of their programme of study. This is again in tune with an earlier study by Muller (2015) involving final year education students at the University of Cologne (Germany), which suggested that the programme of study had no significant effect on the use of behaviour modification strategies by education students.

\section{Conclusion and Recommendations}

Implementing effective correcting behaviour measures is important for successful teaching and learning. In classrooms where teachers are able to effectively manage their classes, students gain a lot from their lessons and are proud of their teachers. This study assessed the practice of pre-service teachers' classroom behaviour modification techniques with particular reference to pre-service teacher interns of Colleges of Education in Ghana. Based on the findings of the study, it can be concluded that the pre-service teacher interns did not regularly practice most of the behaviour modification techniques expected to be used for effective classroom management during the internship programme. This can adversely affect their classroom management performance as teachers. Therefore, teacher training programmes in Ghana need to be strengthened to address this deficiency. First and foremost, a special attention should be given to the field of Behaviour Modification in the training of teachers. Pre-service teachers must be exposed to both theory and practice by increasing the number of courses pertinent to Behaviour Modification. In so doing, these courses would allow students to practice the skills they are introduced to in their teacher education programme, and having been equipped with the necessary tools, they will have the confidence to use them during both the teaching practice phase and throughout their teaching career.

Accordingly, Colleges of Education and other institutions in charge of teacher formation programmes should lay special emphasis on teaching practice which increases and enriches students' practical experiences as they observe and adopt strategies for successful instruction, engagement, and management of students' disruptive behaviour. Finally, in much the same way, pre-service teachers should be exposed to Behaviour Modification at the very beginning of their preparation, 
providing them with every possible opportunity to broadly relate Behaviour Modification principles and strategies to other course areas and affording them a better understanding and competencies of Behaviour Modification. With improved behaviour modification techniques, it is expected that teaching-learning situation in the classroom would significantly improve.

\section{Acknowledgements}

As authors of this work, we are grateful to the pre-service teachers of the Colleges of Education (in Ghana), who volunteered to be part of this study. As well, we extend our appreciation and gratitude to the management of these same institutions that participated in the study. Finally, we wish to express our sincerest thanks to Professor Stephen Jobson Mitchual of University of Education, Winneba, whose review and suggestions contributed immensely to this study.

\section{Consent and Ethical Approval}

All ethical procedures required were followed. Participants were made to indicate their willingness to participate in the study; written consent has been collected and preserved by the author(s).

\section{Conflicts of Interest}

The authors declare no conflicts of interest regarding the publication of this paper.

\section{References}

Adei, D., \& Kunfaa, E Y. (2007). Occupational Health and Safety Policy in the Operation of the Wood Processing Industry in Kumasi, Ghana. Journal of Science and Technology, 27, 161-173. https://doi.org/10.4314/just.v27i2.33052

Ahiapko, W. (2016). Effects of Educational Environment of Students' Academic Achievement. Journal of Educational Practice, 7, 57-69.

Al-Bustanji, M. A., Almakanin, H. A., Beirat, M., \& Bdour, N. T. A. (2018). Preservice Special Education Teachers' Levels of Knowledge of Behavior Modification Principles. Journal of Studies in Education, 8, 35-50.

Alhassan, L. S. (2000). Beyond the DAP versus Standards Dilemma: Examining the Unforgiving Complexity of Kindergarten Teaching in the United States. Early Childhood Research Quarterly, 22, 39-54. https://doi.org/10.1016/j.ecresq.2006.08.001

Aponsem, P. (2015). Corporal Punishment: A Longitudinal Analysis of the Impact on Educational Attainment. Journal of Personality and Social Psychology, 35, 365-380. https://doi.org/10.1037/0022-3514.35.6.365

Beery, R. C. (1917). Practical School Discipline-Applied Methods (Part 1). Pleasant Hill, $\mathrm{OH}$ : International Academy of Discipline.

Blum, M. H. (1994). The Pre-Service Teacher's Educational Training in Classroom Discipline: A National Survey of Teacher Education Programmes. Doctoral Dissertation. Retrieved from ProQuest Dissertations and Theses database (UMI No. 9434650).

Boakye, K. (2001). Reintroducing Caning in Our Schools? Ghanaian Chronicle, 3 April, p. 1. 
Brace, A. S. (2017). Knowledge of Behaviour Modification Techniques: A Cross Cultural Study among Wesley College of Education, Kumasi, Ghana and St. Hubert College of Education in Oklahoma, USA. American Sociological Review, 54, 485-502.

Bukhari, E. S. (2016). Practice of Behaviour Modification Strategies by Teachers in Hyderabad, Pakistan. Journal of Counselling and Clinical Psychology, 56, 440-447.

Curwin, R. L., \& Mendler, A. N. (1988). Packaged Discipline Problems: Let the Buyer Beware. Educational Leadership, 46, 68-71.

Edumadze, E. (2004). Banning of Corporal Punishment Has Contributed to Indiscipline. Ghana News Agency, 10, 1.

Eshun, J. (2016). Self-Concepts, Self-Esteem, and Behaviour Modification Practices. Journal of Personality and Social Psychology, 50, 35-46.

Gaustard, J. (2005). School Discipline. Devon: Willan Publishing.

Hakan, S., \& Esergül, B. (2015). Pre-Service Teachers' Classroom Management Self-Efficacy Beliefs. International Online Journal of Educational Sciences, 7, 37-50.

Jones, V. F., \& Jones, L. S. (2012). Comprehensive Classroom Management, Creating Communities of Support and Solving Problems (10th ed.). Upper Saddle River, NJ: Pearson.

Kakkad, R. (2012). How a Teacher Should Manage the Classroom? International Journal of Human Resource Management \& Research, 2, 53-62.

Kalagho, N. (2014). High Standards for Effective Discipline. Educational Leadership, 41, 75-76.

Kohut, S. J., \& Dale, G. R. (1979). Classroom Discipline: Case Studies and Viewpoints. Washington DC: National Education Association (NEA).

Main, S., \& Hammond, L. (2008). Best Practice or Most Practiced? Pre-Service Teachers' Beliefs about Effective Behaviour Management Strategies and Reported Self-Efficacy. Australian Journal of Teacher Education, 33, 28-39.

https://doi.org/10.14221/ajte.2008v33n4.3

Mclntosh, C. (2013). Cambridge Advanced Learner's Dictionary. Cambridge, UK: Cambridge University Press.

Mukadam, P., Vyas, S., \& Nayak, H. (2014). Skinner's Programmed Learning vs. Conventional Teaching Method in Medical Education: A Comparative Study. National Journal of Community Medicine, 5, 144-147.

Muller, R. (2015). Knowledge of Final Year Education Students in the University of Cologne, Germany on the Use of Behaviour Modification Strategies. International Centre for Teacher Education, 11, 21-34.

Narebe, N. (2013). Adolescent Development and the Junior High School Environment. Social Work in Education, 21, 238-149.

Neuman, W. L. (2000) Social Research Methods: Qualitative and Quantitative Approaches. Boston, MA: Allyn \& Bacon.

Ngwokabuenui, P. Y. (2015). Students' Indiscipline: Types, Causes and Possible Solutions: The Case of Secondary Schools in Cameroon. Journal of Education and Practice, 6, 64-72.

OECD (2005). Teachers Matter: Attracting, Developing and Retaining Effective Teachers. Paris: OECD Publishing.

Okafor, T. H. (2015). Practice of Behaviour Modification by Teachers in Jos Plateau in Nigeria. Journal of Psychopathology and Behavioral Assessment, 8, 305-316.

Perkins, H. V. (1969). Human Development and Learning. Belmont, CA: Wadsworth 
Publishing Co.

ProTeacher (2005). Behaviour Management Survey. http://www.proteacher.com/classroom management/021905/index.html

Reid, K. (2000). Tackling Truancy in Schools: Practical Manual for Primary and Secondary Schools. London: Routeledge.

Shamina, O. A., \& Mumthas, H. (2018). The Development of Education in British West Africa. London: Thomas Nelson and Sons Ltd.

Shin, S., \& Koh, M. (2008). A Cross-Cultural Study of Students' Behaviours and Classroom Management Strategies in the USA and Korea. Journal of the International Association of Special Education, 9, 13-27.

Stough, F. (2006). Early Childhood Education Programmes in Kenya: Challenges and Solutions. Early Years: An International Journal of Research and Development, 29, 227-236. https://doi.org/10.1080/09575140902984400

The Schools White Paper (2010). The Importance of Teaching. Department for Education-Presented to Parliament by the Secretary of State for Education by Command of Her Majesty. London: Crown Copyright 2010.

Van de Grift, W. J. C. M., Van der Wal, M., \& Torenbeek, M. (2011). Development in Teaching Skills. Pedagogische Studien, 88, 416-432.

Vegas, E., Ganimian, A., \& Jaimovich, A. (2012, February). Learning from the Best: Improving Learning through Effective Teacher Policies. Education Notes 67345, SABER-Teachers Team, World Bank.

Way, C. (2001). Teacher Development: A Strategy for School Improvement. LAB Notes, 3, 2-14.

Were, V. (2006). "Love, Love and More Love for Children": Exploring Preservice Teacher's Understanding of Caring, Teaching and Teacher Education. Educational Psychology Review, 16, 861-872. https://doi.org/10.1016/S0742-051X(00)00031-7

Wesley, D. A., \& Vocke, D. E. (1992, February). Classroom Discipline and Teacher Education. In Paper presented at the Annual Meeting of the Association of Teacher Educators. Westwood: ERIC Document Reproduction Services No. ED 341690. 